\title{
Harnessing phage display technology for generating fully human IgG antibodies that neutralise elapid neurotoxins
}

Karatt-Vellatt, Aneesh; Laustsen, Andreas Hougaard; Masters, Edward W.; Oscoz, Saioa; Pus, Urska; Knudsen, Cecilie; Slavny, Peter; Luther, Alice M.; Leah, Rachael A.; Grifiths, Daniel T.

Total number of authors:

14

Published in:

Toxicon

Link to article, DOI:

10.1016/j.toxicon.2018.10.068

Publication date:

2019

Document Version

Publisher's PDF, also known as Version of record

Link back to DTU Orbit

Citation (APA):

Karatt-Vellatt, A., Laustsen, A. H., Masters, E. W., Oscoz, S., Pus, U., Knudsen, C., Slavny, P., Luther, A. M., Leah, R. A., Grifiths, D. T., Olesen, M. L., Lomonte, B., Gutiérrez, J. M., \& McCafferty, J. (2019). Harnessing phage display technology for generating fully human $\lg G$ antibodies that neutralise elapid neurotoxins. Toxicon, 158(Suppl. 1), s18-s18. [59]. https://doi.org/10.1016/j.toxicon.2018.10.068

\section{General rights}

Copyright and moral rights for the publications made accessible in the public portal are retained by the authors and/or other copyright owners and it is a condition of accessing publications that users recognise and abide by the legal requirements associated with these rights.

- Users may download and print one copy of any publication from the public portal for the purpose of private study or research.

- You may not further distribute the material or use it for any profit-making activity or commercial gain

- You may freely distribute the URL identifying the publication in the public portal 
Page 1 of 1

https://ac.els-cdn.com/S0041010118304768/1-s2.0-S0041010118304768-main.pdf? tid=95959b8d-890d-4a... 04-02-2019 